\title{
THE ANNUAL MEETING
}

Ralph Stueck, Abernethy, Sask., Naturalist, Farmer, Photographer, Lecturer, the "Jack Miner" of the Prairies, became the fifth president of the Saskatchewan Natural History Society at its annual meeting at the Provincial Museum on October 24th. With true naturalists' enthusiasm members came from far and near (three cars and a truck came from Yorkton).

Dr. Houston, chairman, kept a heavy agenda well timed.

Fred Bard, director of the Provincial Museum, welcomed the members to what must be the last meeting in the old museum. He reminded them of their solemn obligation to the citizens of the future. He referred to the plight of the few existing Whooping Cranes due to terrific gun pressure. He hoped the Society would go on record to prohibit shooting of any WHITE birds and to protect Eagles and other affected species.

Mr. Frank Baines, Saltcoats, brought a packsack of native woods made into useful and decorative items. As a pioneer of ' 83 he knew and loved every tree in his community.

Tom Harper, Regina, showed us Saskatchewan in all its variations of plant and animal life.

Maurice Street, Nipawin, Sask.'s foremost bird-bander, came farthest distance to tell many stories of his intriguing way to spend spare time. Ten thousand birds visits his city lot yearly. Billy Mathews has a banding station on his farm. They work together and in the last few years have banded 104 species and 11,000 individual birds. Mr. Street was concerned about the senseless slaughter of beneficial hawks that goes on every year.

Ronald and Donald Hooper, twins of Somme, were youngest speakers on the program. Four years ago they started doing taxidermy, now interested in everything in nature. Peiwee Valley is a fine place to explore: river, hills, lakes and marshes. Fine pictures illustrated their activities.

Art Benson, Regina, spoke on the Antelope in Saskatchewan. Estimated numbers in the early days 20 million, now 15 thousand. Now Montana and Saskatchewan share data and research to control international herds.

Mr. Yanchinski, Naicam, showed slides beautiful in composition, colour and subject of nature in his own backyard.

Bob Arnold, Prince Albert, described his methods of carrying the conservation message into 600 schools in the north, with interesting observations.

Doug. Gilroy, Bredin, showed some of his bird pictures, perfect as usual.

Boyd Wettlaufer, Regina, showed pictures of different sites in Saskatchewan and explained the archaeological findings.

Bernard Gollop, Saskatoon, illustrated with slides the work of the Canadian Wildlife Service.

Ralph Stueck showed his newest colour film of the Whooping Crane.

A day crammed with interest came to a close with the presentation of the first annual Conservation Awards to Mr. Arch Budd, Swift Current, and to Ralph Stueck, Abernethy.

Mr. Budd received the heartiest congratulations on his recent book on Flora of the Prairies; Mr. Stueck on his elevation to the presidency. The Past President, Dr. Houston, had been most energetic and enthusiastic. To him went a great deal of the credit for the changed picture of the Blue Jay finances.

$\mathrm{Mr}$. loyd Carmichael reported about 800 members last year compared to two thousand this year. As Editor he appealed for help from all to make the magazine the best of its kind. 